\title{
$900 \mathrm{MHz}$ pulse-modulated radiofrequency radiation induces oxidative stress on heart, lung, testis and liver tissues
}

\author{
Meric A. Esmekaya ${ }^{1}$, Cigdem Ozer $^{2}$ and Nesrin Seyhan ${ }^{1}$ \\ ${ }^{1}$ Department of Biophysics, Gazi University, Faculty of Medicine Gazi Non-ionizing Radiation Protection (GNRP) Center, \\ Ankara, Turkey \\ ${ }^{2}$ Department of Physiology, Gazi University, Faculty of Medicine, Ankara, Turkey
}

\begin{abstract}
Oxidative stress may affect many cellular and physiological processes including gene expression, cell growth, and cell death. In the recent study, we aimed to investigate whether $900 \mathrm{MHz}$ pulse-modulated radiofrequency $(\mathrm{RF})$ fields induce oxidative damage on lung, heart and liver tissues. We assessed oxidative damage by investigating lipid peroxidation (malondialdehyde, MDA), nitric oxide $\left(\mathrm{NO}_{\mathrm{x}}\right)$ and glutathione $(\mathrm{GSH})$ levels which are the indicators of tissue toxicity. A total of 30 male Wistar albino rats were used in this study. Rats were divided randomly into three groups; control group $(n=10)$, sham group (device off, $n=10$ ) and $900 \mathrm{MHz}$ pulsed-modulated RF radiation group $(n=10)$. The RF rats were exposed to $900 \mathrm{MHz}$ pulsed modulated RF radiation at a specific absorption rate (SAR) level of $1.20 \mathrm{~W} / \mathrm{kg} 20 \mathrm{~min} /$ day for three weeks. $\mathrm{MDA}$ and $\mathrm{NO}_{\mathrm{x}}$ levels were increased significantly in liver, lung, testis and heart tissues of the exposed group compared to sham and control groups ( $p<0.05)$. Conversely GSH levels were significantly lower in exposed rat tissues $(p<0.05)$. No significantly difference was observed between sham and control groups. Results of our study showed that pulse-modulated RF radiation causes oxidative injury in liver, lung, testis and heart tissues mediated by lipid peroxidation, increased level of $\mathrm{NO}_{\mathrm{x}}$ and suppression of antioxidant defense mechanism.
\end{abstract}

Key words: Radiofrequency radiation - Oxidative stress - Malondialdehyde - Glutathione - Nitric oxide

Abbreviations: GSH, gluthatione; MDA, malondialdehyde; RF, radiofrequency; ROS, reactive oxygen species.

\section{Introduction}

Oxidants can be generated in numerous exogenous ways such as chemicals and radiation exposure through redoxcatalysis and encompass reactive oxygen species (ROS), reactive nitrogen species (RNS), sulfur-centered radicals and various others (Abuja and Albertini 2001). Lipid peroxidation is the deleterious consequence of oxidative damage which involves hydrogen abstraction from fatty acids by free radicals. Malondialdehyde (MDA), the end product of the lipid peroxidation is a highly reactive three carbon dialdehyde and one of the most intensively aldehydes formed during lipid per-

Correspondence to: Meric Arda Esmekaya, Department of Biophysics, Gazi University, Faculty of Medicine, 06510 Beşevler, Ankara, Turkey

E-mail: mericarda@yahoo.com oxidation. RNS, such as nitric oxide (NO), a free radical and peroxynitrite $\left(\mathrm{ONOO}^{-}\right)$that is an extremely potent cellular oxidant produced with the reaction of $\mathrm{NO}$ with superoxide $\left(\mathrm{O}_{2}{ }^{-}\right)$act together with other ROS to damage cells, causing nitrosative stress (Squadrito and Pryor 1998). In a healthy human body, the generation of pro-oxidants in the form of ROS and RNS are effectively kept in balance by the various levels of antioxidant defense (Devasagayam et al. 2004). However, when it gets exposed to adverse environmental agents, this delicately maintained balance is shifted in favor of pro-oxidants resulting in oxidative stress. Sub-lethal levels of oxidative stress may activate and inactivate transcription factors, membrane channels, and metabolic enzymes and promote calcium-dependent and phosphorylation signaling pathways (Winterbourn and Hampton 2008).

Scientists have been conducting experimental studies on whether radiofrequency $(\mathrm{RF})$ radiation emitted from cellular 
mobile phones induces oxidative stress on biological tissues or cells and others developed theoretical explanations how these fields could impair free radical re-combinations (WHO 2006 Geneva). Moreover, some authors suggested that mechanism of RF/MW (microwave) radiation damage may be attributable to the induction of oxidative stress leading to free radical generation and radical scavengers' alterations in biological tissues or cells as a result of the interaction of the tissues or cells with RF/MW fields (Cleary et al. 1996; Diem et al. 2005). According to the current assumption electromagnetic (EM) fields may initiate oxygen- and nitrogen-free radical intermediates and several types of tissue injury may be associated with oxidative stress process induced by these fields. EM fields may affect biological cells by interacting electrons during redox reactions (Blank 2008).

Although some authors pointed out the possibility that RF radiation could affect the concentration of free radicals through the radical pair recombination thus increase the oxidant stress on cells or tissues, studies on some specific tissues are very limited. So we aimed to investigate whether low intensity $900 \mathrm{MHz}$-modulated RF radiation induces oxidative damage on lung, heart, liver and testis tissues by assessing the levels of lipid peroxidation and glutathione (GSH) on these tissues. We also measured total $\mathrm{NO}\left(\mathrm{NO}_{\mathrm{x}}\right)$ levels to determine biochemical damage in tissues as an additional parameter to lipid peroxidation and antioxidant level.

\section{Materials and Methods}

\section{Animals and treatments}

Two months old male Wistar albino rats were used in this study. The animals were acclimatized in the temperaturecontrolled conditions $\left(22 \pm 1^{\circ} \mathrm{C}\right)$ and humidity $(50 \pm 10 \%)$ with light/dark cycles of $12 \mathrm{~h}$ and had free access to food and drinking water. None of the animals died during the experiment. Rats were divided randomly into three groups; group I: control group $(n=10)$, group II: sham group $(n=10)$ and group III: RF radiation group $(n=10)$. The RF rats were exposed to $900 \mathrm{MHz}$ pulsed-modulated RF radiation 20 $\mathrm{min} /$ day for three weeks. The sham rats were settled in the exposure cage and applied the same experimental procedure of the exposed group rats, but the exposure device was off. Sham- and RF-exposed animals were kept in the same conditions as the control ones when sham and RF exposures were not performed. At the end of the last day of the exposure, rats were sacrificed by injection of ketamine $(50 \mathrm{mg} / \mathrm{kg})$ and xylazine $(5 \mathrm{mg} / \mathrm{kg})$ combination. The investigation was performed following European Community guidelines and approval by the ethics committee of Gazi University Faculty of Medicine.

\section{Radiofrequency radiation exposure system}

A rectangular horn antenna (Ets-Lindgren, St. Louis, MO, USA) was used as a transmitting antenna which generates RF signals inside polymethyl methacrylate plastics cages $(15 \mathrm{~cm} \times 20 \mathrm{~cm} \times 20 \mathrm{~cm})$ where the rats were restrained. Antenna was fed by a properly selected RF power generator (Agilent Technologies, Santa Clara, CA, USA) that delivers $900 \mathrm{MHz}$ carrier RF waves and connected to a power amplifier (Hittite, Chelmsford, MA, USA) which amplifies the RF signals. The signals were pulse-modulated by rectangular pulses (repetition frequency $217 \mathrm{~Hz}$, pulse width $0.576 \mathrm{~ms}$ ) by using a function generator (Thandar, Cambridgeshire, UK). Cages were placed symmetrically along the axis that is perpendicular to the antenna (Fig. 1) and constantly ventilated to eliminate the external stress and avoid the possibility of any temperature increase inside them.

The applied electric field was measured by using an electric field isotropic probe along the horn antennas axis. At the beginning of exposure, average power density was observed at a reference point which was the midpoint of the bottom of the cage wall facing horn the antenna. The maximum power density was on the axis of the antenna and it was observed that the power density was decreased uniformly with the distance from the antenna's axis. Whole body specific absorption rate (SAR) was approximately calculated according to the formulary of SAR $=\sigma / \rho \cdot\left|\mathrm{E}_{\mathrm{RMS}}\right|^{2}(\mathrm{~W} / \mathrm{kg})$. Where $\sigma$ is the mean electrical conductivity of the whole body $(\mathrm{S} / \mathrm{m}), \rho$ is the mass density $\left(\mathrm{kg} / \mathrm{m}^{3}\right)$ and $\mathrm{E}_{\mathrm{RMS}}$ is the root mean square value of the electric field $(\mathrm{V} / \mathrm{m})$. The whole body average SAR was calculated to be $1.20 \mathrm{~W} / \mathrm{kg}$.

\section{Measurement of tissue lipid peroxidation and GSH levels}

Tissue samples were obtained after measuring lesion areas and frozen immediately by liquid nitrogen then kept in

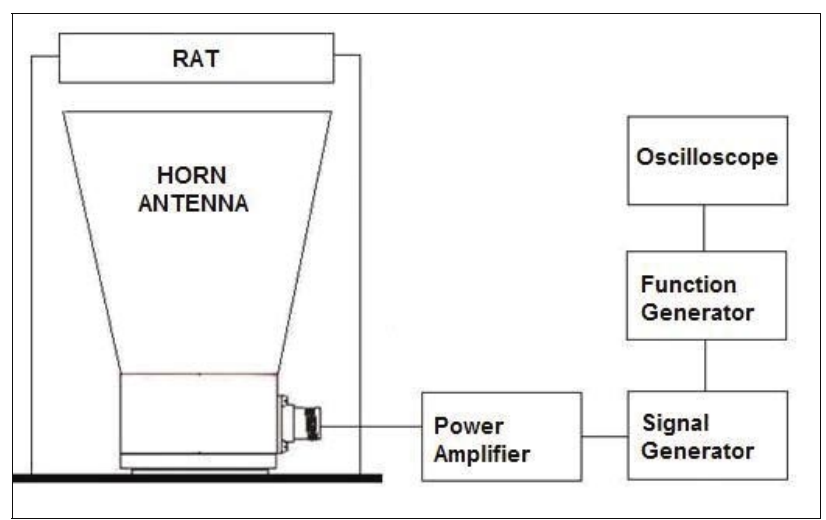

Figure 1. Schematic diagram of the RF exposure system. 
$-70^{\circ} \mathrm{C}$ deep-freeze until the assay. Lipid peroxidation was quantified by measuring the formation of thiobarbituric acid reactive substances (TBARS). Samples were homogenized in ice-cold trichloroacetic acid (1 g tissue in $10 \mathrm{ml}$ $10 \%$ trichloroacetic acid) in a tissue homogenizer (Heideloph Diax 900, Germany). Following centrifugation of the homogenate at $3000 \times g$ for $10 \mathrm{~min}$ (Hermle Z $323 \mathrm{~K}$, Germany), $750 \mu \mathrm{l}$ of supernatant was added to an equal volume of $0.67 \%(\mathrm{~m} / \mathrm{v})$ thiobarbituric acid and heated at $100^{\circ} \mathrm{C}$ for $15 \mathrm{~min}$. The absorbance of the samples was measured at $535 \mathrm{~nm}$. Lipid peroxide levels are expressed in terms of MDA equivalents using an extinction coefficient of $1.56 \times 10^{5} \mathrm{l} \cdot \mathrm{mol}^{-1} \cdot \mathrm{cm}^{-1}$.

The GSH levels were determined by Ellman method with some modifications. Briefly, after centrifugation of the homogenates at $3000 \times g$ for $10 \mathrm{~min}, 0.5 \mathrm{ml}$ of supernatant was added to $2 \mathrm{ml}$ of $0.3 \mathrm{M} \mathrm{Na}_{2} \mathrm{HPO}_{4} \cdot 2 \mathrm{H}_{2} \mathrm{O}$ solution. A $0.2 \mathrm{ml}$ solution of dithiobisnitrobenzoate $(0.4 \mathrm{mg} / \mathrm{ml} 1 \%$ sodium citrate) was added and after mixing, the absorbance at 412 $\mathrm{nm}$ was measured using a spectrophotometer (UV 1208, Shimadsu, Japan) at room temperature immediately. The GSH levels were calculated using an extinction coefficient of $13600 \mathrm{l} \cdot \mathrm{mol}^{-1} \cdot \mathrm{cm}^{-1}$.

\section{Determination of $\mathrm{NO}_{x}$ (Griess assay)}

$\mathrm{NO}_{\mathrm{x}}$ levels were obtained from Elisa reader by vanadium chloride $\left(\mathrm{VCl}_{3}\right) / \mathrm{Griess}$ assay. Before $\mathrm{NO}_{\mathrm{x}}$ determination, tissues were homogenized in five volumes of phosphate buffer saline $(\mathrm{pH}=7)$ and centrifuged at $2000 \times g$ for $5 \mathrm{~min}$. After centrifugation, $0.25 \mathrm{ml}$ of $0.3 \mathrm{M} \mathrm{NaOH}$ was added to $0.5 \mathrm{ml}$ supernatant. The incubation of the samples for $5 \mathrm{~min}$ at room temperature was followed by addition of $0.25 \mathrm{ml}$ of $5 \%(\mathrm{w} / \mathrm{v}) \mathrm{ZnSO}_{4}$ for deproteinization. This mixture was then centrifuged at $3000 \times g$ for $20 \mathrm{~min}$ and supernatants were used for the assays. Nitrate standard solution was serially diluted and the plates were loaded with samples $(100 \mu \mathrm{l})$. Then Vanadium III chloride $(\mathrm{VCl} 3)(100 \mu \mathrm{l})$ and Griess reagents sulphanilamide (SULF) $(50 \mu \mathrm{l})$ and N-(1-naphthyl) ethylenediamine dihydrochloride (NEDD) $(50 \mu \mathrm{l})$ were added to each well. After incubation in $37^{\circ} \mathrm{C}$ for $45 \mathrm{~min}$, samples were measured at $540 \mathrm{~nm}$ using ELISA reader (Miranda et al. 2001).

\section{Statistical Analysis}

All data were presented as mean values \pm SD. Differences among three groups were analyzed by one way analysis of variance (ANOVA). Mann-Whitney $U$ test was used for pairwise comparisons among groups. The accepted level of significance was set at $p<0.05$. Data were analyzed with statistical package (SPSS) version 13.0.

\section{Results}

The MDA levels of heart, liver and lung tissues

Tissue MDA level of liver (Table 1) and lung (Table 2) tissues was significantly higher $(p<0.001)$ in RF-exposed group in comparison with sham and control tissues. A significant increase was observed also in heart MDA level of RF-exposed rats compared to sham and control rats $(p<0.05)$ (Table 3$)$. The most dramatic increase in the MDA level of the tissues was observed in testis tissue. MDA level of testis was marginally higher in RF exposed group than sham and control groups $(p<0.001)$ (Table 4$)$. No significant difference was observed in terms of tissue MDA level between sham and control groups in each tissue.

\section{$N O_{x}$ levels in heart, liver and lung tissues}

Liver $\mathrm{NO}_{\mathrm{x}}$ level was significantly higher in RF-exposed group than sham and control groups $(p<0.001)$ (Table 1$)$. The level of $\mathrm{NO}_{\mathrm{x}}$ increased significantly in RF-exposed lung tissues $(p<0.01)$ (Table 2). $\mathrm{NO}_{\mathrm{X}}$ level of heart increased in RF-exposed group compared to sham and control groups $(p<0.001)$ (Table 3). Tissue level of $\mathrm{NO}_{\mathrm{x}}$ was quite high in RF-exposed testis tissues $(p<0.001)$ (Table 4$)$. No statistically difference was seen between sham and control groups.

\section{The GSH levels of heart, liver and lung tissues}

GSH level of liver decreased following to RF exposure in exposed group compared to sham and control groups $(p<$ 0.001) (Table 1). Lung GSH level reduced significantly in RF-exposed group $(p<0.01)$ (Table 2$)$. A significant decrease in GSH level of heart was observed in RF-exposed group in comparison with sham and control groups $(p<0.001)$ (Table 3). Exposure to RF radiation reduced GSH level of testis tissues about $50 \%$ compared to those of sham and control groups $(p<0.001)$ (Table 4$)$. There was no statistically significant difference in GSH levels between sham and control groups.

\section{Discussion}

Increasing evidence has indicated that RF radiation has the potential of inducing oxidative stress in biological systems via free radicals by enhancing lipid peroxidation and reducing antioxidant levels. In the recent study, we showed that chronic exposure to $900 \mathrm{MHz}$ pulse-modulated $\mathrm{RF}$ radiation can cause lipid peroxidation, nitrogenic stress and antioxidant suppression in various tissues. MDA levels of liver, heart, lung and testis tissues increased significantly in 
Table 1. Mean liver tissue levels of MDA, total NO and GSH in control, sham and RF-exposed groups

\begin{tabular}{lccc}
\hline Group & $\mathrm{MDA}(\mathrm{nmol} / \mathrm{g})$ & $\mathrm{NO}_{\mathrm{x}}(\mu \mathrm{mol} / \mathrm{g})$ & $\mathrm{GSH}(\mathrm{nmol} / \mathrm{g})$ \\
\hline control & $9.02 \pm 1.1$ & $12.44 \pm 1.96$ & $3.36 \pm 0.45$ \\
sham & $9.31 \pm 0.91$ & $11.35 \pm 1.42$ & $3.14 \pm 0.31$ \\
RF-exposed $^{*}$ & $14.78 \pm 1.2$ & $16.00 \pm 2.99$ & $2.09 \pm 0.26$ \\
\hline
\end{tabular}

The values are means $\pm \mathrm{SD} ; n=10 .{ }^{*} p<0.01$, RF-exposed $v$. control or sham groups.

Table 2. Mean lung tissue levels of MDA, total NO and GSH in control, sham and RF-exposed groups

\begin{tabular}{lcrc}
\hline Group & $\mathrm{MDA}(\mathrm{nmol} / \mathrm{g})$ & $\mathrm{NO}_{\mathrm{x}}(\mu \mathrm{mol} / \mathrm{g})$ & $\mathrm{GSH}(\mathrm{nmol} / \mathrm{g})$ \\
\hline control & $10.95 \pm 2.56$ & $16.21 \pm 1.63$ & $3.24 \pm 0.27$ \\
sham & $11.45 \pm 2.16$ & $15.23 \pm 1.56$ & $3.22 \pm 0.34$ \\
RF-exposed $^{*}$ & $23.62 \pm 4.14$ & $19.97 \pm 2.71$ & $2.99 \pm 0.25$ \\
\hline
\end{tabular}

The values are means $\pm \mathrm{SD} ; n=10 .{ }^{\star} p<0.01$, RF-exposed $v$. control or sham groups.

RF group compared to sham and control groups. Similarly tissue $\mathrm{NO}_{\mathrm{x}}$ levels were significantly higher in RF-exposed tissues. However, GSH levels showed significant reduction in exposed tissues. The results of our study verified the hypothesis that RF radiation may cause oxidative damage in biological tissues. Moreover, we observed that the magnitude of the damage depended on type of the tissue.

The change in MDA and GSH levels in exposed rats reflected pathophysiological effects of pulse modulated RF fields on liver tissue. Oxidative stress may accelerate the peroxidation reactions of lipids in liver (Yasa et al. 1999). It has been reported that patients diagnosed with degenerative liver diseases have higher level of lipoperoxide in their liver tissues and several forms of liver diseases have been shown to be associated with oxidative tissue injury (Suematsu et al. 1981). Dasdag et al. (2008) reported increased levels of MDA and of the total oxidant status in liver tissue of the Wistar albino rats exposed to $900 \mathrm{MHz} \mathrm{RF}$ radiation. However, they found no significant endpoints in terms of catalase, myeloperoxidase, total antioxidant capacity levels. Koyu et al. (2005) investigated the effects of MW radiation on the liver oxidant/antioxidant system, and the possible protective effects of caffeic acid phenethyl ester (CAPE) on liver tissue. They observed increased level of lipid peroxidation and decreased activity of GSH-Px in the liver tissue of the 1800 $\mathrm{MHz}$ RF radiation exposed rats. Moreover the authors noted that CAPE prevented the oxidative injury in liver tissue due to $\mathrm{RF}$ radiation exposure. The significant increase in lipid peroxidation level in exposed rat liver tissues may be due to increase of $\mathrm{NO}_{\mathrm{x}}$ level in the recent study. Overproduction of $\mathrm{NO}$ is one of the most important sources of oxidative
Table 3. Mean heart tissue levels of MDA, total NO and GSH in control, sham and RF-exposed groups

\begin{tabular}{lccc}
\hline Group & $\mathrm{MDA}(\mathrm{nmol} / \mathrm{g})$ & $\mathrm{NO}_{\mathrm{x}}(\mu \mathrm{mol} / \mathrm{g})$ & $\mathrm{GSH}(\mathrm{nmol} / \mathrm{g})$ \\
\hline control & $6.07 \pm 1.11$ & $7.83 \pm 1.39$ & $1.84 \pm 0.1$ \\
sham & $5.93 \pm 0.86$ & $6.96 \pm 1.37$ & $1.72 \pm 0.29$ \\
RF-exposed $^{*}$ & $7.3 \pm 0.93$ & $13.09 \pm 2.6$ & $1.01 \pm 0.11$ \\
\hline
\end{tabular}

The values are means \pm SD; $n=10 .{ }^{\star} p<0.01$, RF-exposed $v s$. control or sham groups.

Table 4. Mean testis tissue levels of MDA, total NO and GSH in control, sham and RF-exposed groups

\begin{tabular}{lcrc}
\hline Group & $\mathrm{MDA}(\mathrm{nmol} / \mathrm{g})$ & $\mathrm{NO}_{\mathrm{x}}(\mu \mathrm{mol} / \mathrm{g})$ & $\mathrm{GSH}(\mathrm{nmol} / \mathrm{g})$ \\
\hline control & $6.48 \pm 0.93$ & $9.92 \pm 1.72$ & $4.1 \pm 0.37$ \\
sham & $6.49 \pm 0.92$ & $11.87 \pm 2.07$ & $4.14 \pm 0.42$ \\
RF-exposed $^{*}$ & $15.11 \pm 1.37$ & $32.99 \pm 3.83$ & $2.25 \pm 0.39$ \\
\hline
\end{tabular}

The values are means $\pm \mathrm{SD} ; n=10 .{ }^{\star} p<0.01$, RF-exposed $v$. control or sham groups.

damage in liver (Beckman et al. 1990). The reaction of NO with $\mathrm{O}_{2}{ }^{--}$can produce the $\mathrm{ONOO}^{-}$which can cause lipid peroxidation.

The results of our study also showed that the levels of $\mathrm{MDA}$ and $\mathrm{NO}_{\mathrm{x}}$ may be increased in heart tissue due to RF radiation exposure. These indicate that $\mathrm{RF}$ radiation may act as a stressor on heart tissue as well. Our results were consistent with those of Ozgüner et al. (2005), who observed increased level of NO and MDA in rat myocardial tissue as a result of the exposure to $900 \mathrm{MHz} \mathrm{RF}$ radiation. NO is a major intracellular messenger synthesized by $\mathrm{NO}$ synthetase in vascular endothelium and converted into more stable forms nitrite $\left(\mathrm{NO}_{2}{ }^{-}\right)$and nitrate $\left(\mathrm{NO}_{3}{ }^{-}\right)$in plasma. It mediates a variety of biological functions including cardiovascular homeostasis, yet overproduction of $\mathrm{NO}$ has been implicated as a cytotoxic factor in a variety of pathophysiological processes. Olsen et al. (1977) observed bradycardia in isolated and perfused rat hearts that were maintained in $20^{\circ} \mathrm{C}$ and exposed to 960 $\mathrm{MHz}$ continuous MW radiation.

Lung is a major ROS production organ having a large surface that is constantly in contact with pollutants. This makes lung to need a strong antioxidant defense system to protect it against oxidative/nitrosative stressors. The oxidant/antioxidant imbalance in lung may activate redoxsensitive transcription factors which regulate the protective antioxidant genes. GSH is a major extracellular protective antioxidant against oxidative/nitrosative stresses, which plays a key role in the control of pro-inflammatory processes in the lung. The decrease GSH level in the lung of exposed rats showed that this protective mechanism was reduced due to $\mathrm{RF}$ radiation exposure. The low level of GSH in lung tissues 
of the RF-exposed rats may be associated with increase of the production of lipid peroxidation and NO. It is known that increased level of ROS can alter the GSH redox state. Moreover, increased level of lipid peroxidation impairs membrane function and inactivates membrane-bound receptors and enzymes that result in increase in the tissue permeability which has been implicated in the pathogenesis inflammatory lung disorders (Rahman and MacNee 2000).

The most dramatic increase in lipid peroxidation and decrease in antioxidant levels of the RF-exposed rats were observed in testis tissue. The obtained results indicated that $900 \mathrm{MHz}$ pulse-modulated RF radiation exposure is quite detrimental on testis tissue and RF fields induce an unbalance between production and the neutralization of prooxidant and antioxidant processes and cause oxidative damage in testis. Similar to our study, Mailankot et al. (2009) demonstrated increased lipid peroxidation and reduced GSH content in the testis and epididymis of 10-12 weeks old male Wistar rats exposed to GSM mobile phone radiation $1 \mathrm{~h} /$ day for 28 days. They also observed reduced percentage of motile sperm. De Iuliis et al. (2009) found increased level of ROS and higher DNA damage due to RF radiation exposure. Agarwal et al. (2009) reported significant increase in ROS level and significant decrease in ROS-TAC score in unprocessed ejaculated human semen which were taken from each patient that were exposed to cellular phone radiation for $1 \mathrm{~h}$.

Due to rich polyunsaturated fatty acid content human spermatozoa plasma membranes are highly sensitive to ROSinduced damage. It is considered that lipid peroxidation is the key factor in ROS-induced sperm damage leading to decrease in sperm count, loss of motility, abnormal morphology and reduced capacity of sperm oocyte penetration and infertility (Sikka 1996; Storey 1997). There is strong clinical evidence that men diagnosed with infertility have significantly higher levels of ROS (Pasqualotto et al. 2000). Some of the reports have suggested a possible linkage between mobile phone usage and male infertility (Baste et al. 2008). Decreased sperm count and capacity of quails were reported by McRee et al. (1983) as a result of MW exposure. Cleary et al. (1996) showed that RF radiation may reduce fertilizing capacity of spermatozoa. Agarwal et al. (2009) suggested that RF EMRinduced oxidative stress in semen may be responsible for decreased sperm motility and viability.

We observed an enormous increase in the level of $\mathrm{NO}_{\mathrm{x}}$ in testis tissue due to pulse-modulated RF radiation exposure for 21 days. Tissue level of $\mathrm{NO}_{\mathrm{x}}$ was marginally higher in RF-exposed testis tissues $(32.99 \mu \mathrm{mol} / \mathrm{g})$ than sham $(11.87$ $\mu \mathrm{mol} / \mathrm{g})$ and control tissues $(9.92 \mu \mathrm{mol} / \mathrm{g})$. Although a continent amount of $\mathrm{NO}$ in seminal plasma is essential for normal reproductive function and sperm motility, at supra physiological levels it may lead to testicular abnormalities by inhibiting sperm production and motility (Rosselli et al. 1995; Donnelly et al. 1997; Balercia et al. 2004) through formation of
$\mathrm{ONOO}^{-}$(Kisa et al. 2004). Human studies showed that infertile males have higher concentration of NO in seminal plasma than the healthy males (Nobunago et al. 1996). Furthermore, high amount of NO in seminal plasma is an important factor in sperm DNA damage (Saleh et al. 2002).

In the recent study, we showed that $900 \mathrm{MHz}$ pulse-modulated RF radiation is capable of inducing oxidative stress. This induction was mediated by increase of lipid peroxidation and the reduction of GSH. The study also gave evidence that RF radiation might enhance $\mathrm{NO}$ production. The results of our study are evident that pulse-modulated RF emissions may act as an environmental stressor and cause oxidative and nitrogenic damage in lung, liver, testis and heart tissues. Oxidative stress is known to underlie many human diseases including atherosclerosis, heart failure, myocardial infarction, chronic liver and lung diseases, infertility, etc. Our results suggested that mobile phone use should be limited.

\section{References}

Abuja P. M., Albertini R. (2001): Methods for monitoring oxidative stress, lipid peroxidation and oxidation resistance of lipoproteins. Clin. Chim. Acta. 306, 1-17 doi:10.1016/S0009-8981(01)00393-X

Agarwal A., Desai N. R., Makker K., Varghese A., Mouradi R., Sabanegh E., Sharma R. (2009): Effects of radiofrequency electromagnetic waves (RF-EMW) from cellular phones on human ejaculatedsemen: an in vitro pilot study. Fertil. Steril. 92, 1318-1325 doi:10.1016/j.fertnstert.2008.08.022

Balercia G., Moretti S., Viynini A., Mayaynini M., Mantero F., Boscaro M. (2004): Role of nitric oxide concentrations on human sperm motility. J. Androl. 25, 245-249

Baste V., Riise T., Moen B. (2008): Radiofrequency electromagnetic fields; male infertility and sex ratio of offspring. Eur. J. Epidemiol. 23, 369-377

doi:10.1007/s10654-008-9236-4

Beckman J. S., Beckman T. W., Chen J. (1990): Apparent hydroxyl radical production by peroxynitrite: implications for endothelial injury from nitric oxide and superoxide. Proc. Natl. Acad. Sci. 87, 1620-1624

doi:10.1073/pnas.87.4.1620

Blank M. (2008): Protein and DNA reactions stimulated by electromagnetic fields. Electromagn. Biol. Med. 27, 3-23 doi:10.1080/15368370701878820

Cleary S. F., Du Z., Cao G., Liu L. M., McCrady C. (1996): Effect of isothermal radiofrequency radiation on cytolytic $\mathrm{T}$ lymphocytes. FASEB J. 10, 913-919

Dasdag S., Bilgin H. M., Akdag M. Z., Celik H., Aksen F. (2008): Effect of long term mobile phone exposure on oxidativeantioxidative processes and nitric oxide in rats. Biotechnol. \& Biotechnol. 22, 992-997

De Iuliis G. N., Newey R. J., King B. V., Aitken R. J. (2009): Mobile phone radiation induces reactive oxygen species production and DNA damage in human spermatozoa in vitro. PLoS One 4, 6446 doi:10.1371/journal.pone.0006446 
Devasagayam T. P., Tilak J. C., Boloor K. K., Sane K. S., Lele R. D., Ghaskadbi, R. D. (2004): Free radicals and antioxidants in human health: Current status and future prospects. J. Assoc. Physicians India 52, 794-804

Diem E., Schwarz C., Adlkofer F., Jahn O., Rudiger H. (2005): Non-thermal DNA breakage by mobile-phone radiation (1800 $\mathrm{MHz}$ ) in human fibroblasts and in transformed GFSH-R17 rat granulosa cells in vitro. Mutat. Res. 583, 178-183

Donnelly E., Lewis S. H., Tompson W., Chakaravarty U. (1997): Sperm nitric oxide and motility: the effects of nitric oxide synthase stimulation and inhibition. Mol. Hum. Reprod. 3, 755-762 doi:10.1093/molehr/3.9.755

Kisa U., Basar M. M., Ferhat M., Yilmaz E., Basar, H (2004): Testicular tissue nitric oxide and thiobarbituric acid reactive substance levels: evaluation with respect to the pathogenesis of varicocele Urol. Res. 32, 196-199 doi:10.1007/s00240-004-0401-2

Koyu A., Naziroglu M., Özgüner F. (2005): Caffeic acid phenethyl ester modulates $1800 \mathrm{MHz}$ microwave-induced oxidative stress in rat liver. Electromagn. Biol. Med. 24, 135-142 doi:10.1080/15368370500253787

Mailankot M., Kunnath A. P., Jayalekshmi H., Koduru B., Valsalan R. (2009): Radio frequency electromagnetic radiation (RF-EMR) from GSM $(0.9 / 1.8 \mathrm{GHz})$ mobile phones induces oxidative stress and reduces sperm motility in rats. Clinics 64, 561-565 doi:10.1590/S1807-59322009000600011

McRee D. I., Thoxton J. P., Parkhurst C. R. (1983): Reproduction in male Japanese quail exposed to microwave radiation during embryogeny. Radiat. Res. 96, 51-58 doi: $10.2307 / 3576163$

Miranda K. M., Espey M. G., Wink D. A. (2001): A rapid, simple spectrophotometric method for simultaneous detection of nitrate and nitrite. Nitric Oxide 5, 62-71 doi:10.1006/niox.2000.0319

Nobunago T., Tokugawa Y., Hashimoto K., Kubota Y., Sawai K. (1996): Elevated nitric oxide concentration in the seminal plasma of infertile males: nitric oxide inhibits sperm motility. Am. J. Reprod. Immunol. 36, 193-197

Olsen R. G., Lords J. L., Durney C. H. (1977): Microwave-induced chronotropic effects in the isolated rat heart. Ann. Biomed. Eng. 5, 395-409 doi:10.1007/BF02367318

Ozguner F., Altinbas A., Ozaydin M., Dogan A., Vural H., Kisioglu A. N., Cesur G., Yildirim N. G. (2005): Mobile phone-induced myocardial oxidative stress: protection by a novel antioxidant agent caffeic acid phenethyl ester. Toxicol. Ind. Health 21, 223-230 doi:10.1191/0748233705th228oa

Pasqualotto F. F., Sharm R. K., Nelson D. R., Thomas A. J., Agarwal A. (2000): Relationship between oxidative stress, semen characteristics, and clinical diagnosis in men undergoing infertility investigation. Fertil. Steril. 73, 459-464 doi:10.1016/S0015-0282(99)00567-1

Rahman I., MacNee W. (2000): Oxidative stress and regulation of glutathione in lung inflammation. Eur Respir. J. 16, 534-554 doi:10.1034/j.1399-3003.2000.016003534.x

Rosselli M., Dubey R. K., Imthurn B., Macas E., Keller P. J. (1995): Effects of nitric oxide on human spermatozoa: evidence that nitric oxide decreases sperm motility and induces sperm toxicity. Hum. Reprod. 10, 1786-1790

Saleh R. A., Agarwal A., Nelson D. R., Nada E. A., El-Tonsy M. H., Alvarez J. G., Thomas A. J., Sharma R. (2002): Increased sperm nuclear DNA damage in normozoospermic infertile men: a prospective study. Fertil. Steril. 78, 313-318 doi:10.1016/S0015-0282(02)03219-3

Sikka S. C. (1996): Oxidative stress and role of antioxidants in normal and abnormal sperm function. Front. Biosci. 1, 78-86

Storey B. T. (1997): Biochemistry of the induction and prevention of lipoperoxidative damage in human spermatozoa. Mol. Hum. Reprod. 3, 203-213

doi:10.1093/molehr/3.3.203

Suematsu T., Matsumura T., Sato N., Miyamoto T., Ooka T., Kamada T., Abe H. (1981): Lipid peroxidation in alcoholic liver disease in humans. Alcohol. Clin. Exp. Res. 5, 427-430 doi:10.1111/j.1530-0277.1981.tb04926.x

Squadrito G. L., Pryor W. A. (1998): Oxidative chemistry of nitric oxide: the roles of superoxide, peroxynitrite, and carbon dioxide. Free Radic. Biol. Med. 25, 392-403 doi:10.1016/S0891-5849(98)00095-1

Winterbourn C. C., Hampton M. B. (2008): Thiol chemistry and specificity in redox signaling. Free Radic. Biol. Med. 45, 549-561 doi:10.1016/j.freeradbiomed.2008.05.004

World Health Organization. (2006): WHO research agenda for radio frequency fields. Geneva, pp. 1-10

Yasa M. H., Kacmaz M., Ozturk H. S., Durak I. (1999): Antioxidant status of erythrocytes from patients with cirrhosis. Hepatogastroenterology 46, 2460-2463

Received: March 24, 2010

Final version accepted: September 14, 2010 